Anđa Zobenica ${ }^{1}$

Medicinski fakultet

Univerzitet u Novom Sadu

Ksenija Kolundžija

Medicinski fakultet

Univerzitet u Novom Sadu
UDC: $371.213: 376-056.26 /$

doi: 10.19090/ps.2019.2.177-185

Primljen: 10. 5. 2019.

Prihvaćen: 17. 11. 2019.

STRUČNI NAUČNI RAD

\title{
MENJAJU LI SE STAVOVI NASTAVNIKA PREMA INKLUZIJI?
}

\author{
Apstrakt
}

Inkluzivno obrazovanje predstavlja veliku promenu u obrazovnom procesu. Za uspeh ovog procesa od ključnog su značaja svi akteri koji učestvuju u njemu. Upravo zbog toga, cilj ovog istraživanja je bio utvrditi stavove i emocionalne reakcije nastavnika prema procesu inkluzije. U okviru istraživanja korišćena su tri upitnika: Upitnik opštih demografskih podataka, Upitnik o stavovima nastavnika prema inkluzivnim odeljenjima (Scale of Teacher's Attitudes Toward Inclusive Classrooms) i upitnik koji se odnosi na emocionalne reakcije nastavnika prema deci sa smetnjama u razvoju (Emotional Reaction Scale). Istraživanje je obuhvatilo 106 nastavnika iz osam osnovnih škola na području teritorije Vojvodine. Rezultati istraživanja ukazuju na to da su stavovi nastavnika prema inkluziji samo blago pozitivni $(2,75)$, emocionalne reakcije prema deci sa smetnjama u razvoju su pozitivne $(4,49)$, i da će nastavnici koji ispoljavaju pozitivne emocionalne reakcije prema deci sa smetnjama u razvoju ispoljavati i pozitivnije stavove prema samoj inkluziji u odnosu na nastavnike koji imaju manje pozitivne ili čak negativne emocionalne reakcije $(r=.58, p<.01)$. Uspeh inkluzije je znatno veći u odeljenjima u kojima su emocionalne reakcije nastavnika i njihovi stavovi pozitivni u odnosu na odeljenja gde su negativni.

Ključne reči: Inkluzija, Posebne obrazovne potrebe, Stavovi, Nastavnici

\section{Uvod}

Godinama unazad stavovi prema populaciji učenika sa smetnjama su bili segregirajući i odbacujući. Negativni stavovi su još više doprinosili izolaciji ove populacije učenika. Međutim, uvođenjem inkluzije stvari se menjaju, implementacija inkluzije doprinela je integraciji dece sa smetnjama u razvoju u redovne škole ali i promeni

\footnotetext{
${ }^{1}$ andjazobenica95@gmail.com
} 
stavova prema njima. Promene u stavovima u pozitivnom smeru su neophodne kako bi se osigurao uspeh inkluzivnog procesa, upravo zbog toga se veliki broj studija bavi njima.

Na osnovnoškolskom uzrastu uspeh inkluzije zavisi prvenstveno od osoba koje rade sa decom, odnosno od učitelja i nastavnika koji predstavljaju jedan od ključnih činilaca samog procesa, a njihov osećaj neadekvatnosti i negativni stavovi koji su prisutni u izvesnom broju slučajeva mogu predstavljati značajnu barijeru u inkluzivnom obrazovanju dece sa smetnjama u razvoju (Rajović, Jovanović, 2010).

Upravo zbog pozitivne korelacije između stavova nastavnika i njihovog ponašanja potrebno je proučiti ih, jer promene u stavovima nastavnika u pozitivnom smeru stvaraju veće mogućnosti za uključivanje učenika sa potrebom za dodatnom podrškom u redovnu školu (Brojčin, 2013). Pozitivan stav nastavnika prema inkluziji je veoma bitan naročito u ranom osnovnoškolskom periodu jer je nastavnik osoba koja se u tom periodu prihvata kao autoritet i neko čiji model ponašanja usvajaju gotovo svi učenici u učionici (Galović, Brojčin, Glumbić, 2014).

Prvenstveno nastavnici ali i vršnjaci u odeljenju predstavljaju ključnu podršku i oni su ti koji treba da pruže pomoć detetu sa smetnjama u razvoju kako bi se ono suočilo sa brojnim izazovima koji stoje na putu njegovog obrazovanja u redovnoj školi, počevši od fizičkih i arhitektonskih barijera koje su prisutne u najvećem broju slučajeva pa sve do akademskih, socijalnih i emocionalnih barijera koje stoje na putu ka ostvarenju osnovnih ciljeva školovanja. Postojanje podrške od strane nastavnika doprinosi celokupnom razvoju učenika sa potrebom za dodatnom podrškom (Rajović, Jovanović, 2010).

Osim stavova ključnu ulogu u odnosu između nastavnika i deteta sa potrebom za dodatnom podrškom igraju i emocije nastavnika koje predstavljaju konativnu komponentu stava, one podjednako kao i sami stavovi motivišu ponašanje i delovanje nastavnika. Inkluzivno obrazovanje predstavlja jednu veliku promenu u obrazovnom procesu, a svaka promena je praćena emocionalnom reakcijom, nemoguće je razdvojiti emocije od promena, jedno obuhvata drugo, stoga je bitno obratiti pažnju i na ovaj aspekt funkcionisanja nastavnika koji bitno utiče na njihov odnos sa učenicima (Hargraeves, 2004).

Inkluzija podrazumeva uvažavanje različitosti među učenicima, temelji se na dečijim pravima i individualnom pristupu svakom učeniku (Đorđević,2014), a za samu individualizaciju pristupa odgovorni su nastavnici, te i ovo ukazuje na uticaj koji stavovi nastavnika imaju na tok edukacije učenika i obrazovni proces uopšte (Jovanović, Popadić, 2016).

Korist od inkluzije imaju ne samo deca sa potrebom za dodatnom podrškom već i njihovi vršnjaci kao i sve druge osobe koje su uključene u nastavni proces. U inkluzivnoj učionici podstiče se socijalizacija i uvažavanje različitosti, a usvajanje životnih veština je moguće i kod jednih i kod drugih učenika. U inkluzivnoj školi dakle svi treba da uče zajedno i dobijaju kvalitetno obrazovanje (Giacchi, 2003). 
Na prvom mestu obrazovna a onda i šira socijalna integracija predstavlja važan uslov za odstranjivanje negativnih reakcija društva kojima su ove osobe bile izložene dugi niz godina u prošlosti. Dakle, osnovni preduslov inkluzije jeste promena stavova, vrednosti i ponašanja prema deci sa potrebom za dodatnom podrškom, što se može postići kroz međusobni kontakt sa njima, zajedničkim delovanjem i učenjem, kroz pozitivna iskustva kako sa nastavnicima tako i sa vršnjacima, a upravo škola jeste mesto koje treba da bude pokretač ovih promena i mesto gde se različitost mora prepoznati, poštovati i ceniti (Borić, Tomić, 2012).

\section{Metodologija istraživanja}

Problem ovog istraživanja odnosi se na prepoznavanje stavova nastavnika, jer su promene u stavovima nastavnika u pozitivnom smeru ključne za uspeh inkluzivnog procesa. Cilj istraživanja je bio utvrditi stavove $\mathrm{i}$ emocionalne reakcije nastavnika prema procesu inkluzije. U okviru istraživanja korišćena su tri upitnika, upitnik koji se odnosi na opšte demografske podatke, upitnik kojim smo procenjivali stavove nastavnika prema inkluziji i upitnik koji procenjuje emocionalne reakcije nastavnika prema deci sa smetnjama u razvoju. Istraživanjem je obuhvaćeno 106 nastavnika iz osam osnovnih škola na području teritorije Vojvodine. Istraživanje je realizovano u periodu od aprila do jula 2018. godine.

Upitnikom opštih demografskih podataka prikupili smo informacije koje se odnose na pol, starost, na godine radnog staža, kao i na godine iskustva u radu sa decom sa smetnjama u razvoju.

Za ispitivanje stavova nastavnika prema inkluziji koristili smo instrument: Stavovi nastavnika prema inkluzivnim odeljenjima (Scale of Teacher's Attitudes Toward Inclusive Classrooms-STATIC), (Coharan,1999). Ovaj instrument se sastoji od 20 stavki koje se tiču uključivanja učenika sa potrebom za dodatnom podrškom u inkluzivne učionice. Nastavnici i učitelji su za svaku izjavu iznosili svoje slaganje koristeći šestostepenu Likertovu skalu, ova skala se dakle sastoji iz 6 tačaka, a stepen slaganja sa izjavom se kreće od: 0 - potpuno se ne slažem, 1 - ne slažem se, 2 - nisam siguran, ali se ne slažem, 3 - nisam siguran, ali se slažem, 4 - slažem se, 5 - u potpunosti se slažem. Kada se vrši ocenjivanje ove skale potrebno je da se ključni ajtemi 3, 4, 7, 9, 13 i 15 obrnuto skoruju. Ukupan zbir odgovora na svih dvadeset stavki se posmatra kao odnos nastavnika prema inkluziji. Za nastavnike koji imaju više skorove smatra se da je njihov stav prema inkluziji pozitivniji, dok nastavnici koji imaju niže skorove imaju manje pozitivne ili čak negativne stavove prema inkluziji (Walker, 2017).

Naredni instrument koji je korišćen za procenu emocinalnih reakcija nastavnika jeste skala emocionalne reakcije (Emotional Reaction Scale), (Avramidis et al, 2000). Ova skala se sastoji od bipolarnih prideva koji ocenjuju emocionalne reakcije nastavnika i učitelja prema deci sa smetnjama u razvoju. Ona se sastoji iz sedam stavki pri čemu smo mi još jednu stavku naknadno dodali u ovu skalu. Dodata stavka se odnosi 
na decu sa Daunovim sindromom, razlog uvođenja stavke je povezan sa tim da je u poslednje vreme došlo do porasta broja ove dece u redovnim osnovnim školama. Ovih osam stavki sastojalo se od bipolarnih prideva kao što su ,pesimistično - optimistično“ ili „, ,uznemireno - opušteno“. Od nastavnika je traženo da na skali od 1 do 7 , zaokruže broj koji najbliže odgovara pridevu koji opisuje njihova osećanja. Ukoliko je ispitanik visoko ocenio ovu skalu smatralo se da ima pozitivanije izraženu emociju prema deci sa smetnjama u razvoju (Mahony, 2016).

Istraživanjem je obuhvaćeno 106 nastavnika iz osam redovnih osnovnih škola, većinu uzorka činile su pripadnice ženskog pola $(80,2 \%)$, dok su manji deo uzorka činili muškarci (19,8\%), što i odgovara strukturi zaposlenog nastavnog osoblja u osnovnim školama u pogledu pola. Istraživanjem su obuhvaćeni ispitanici starosti od 27 do 63 godine. Radni staž naših ispitanika kretao se u rasponu od 1 - 38 godina (AS-17).

Prikupljeni podaci su obrađeni u okviru statističkog paketa SPSS - Statistics for Windows 24. Analiza podataka obuhvatila je metode deskriptivne i analitičke statistike i testiranje hipoteza (statističke značajnosti). U deskriptivnom delu analize prikazani su apsolutni brojevi, procenti, aritmetička sredina, opseg vrednosti i standardna devijacija. U analizi podataka je korišćena Pirsonova korelacija.

\section{Rezultati}

Primenom upitnika Scale of Teacher's Attitudes Toward Inclusive Classroom želeli smo da ispitamo stavove nastavnika prema inkluzivnim odeljenjima, nastavnici su u okviru ovog upitnika trebali da izraze stepen slaganja sa svakom od 20 ponuđenih izjava, na taj način što su trebali da zaokruže broj od $0-5$, pri čemu je 0 predstavljalo potpuno neslaganje sa izjavom dok je 5 predstavljalo potpuno slaganje sa istom. Neke od izjava u okviru ovog upitnika jesu: uveren sam u svoju sposobnost da podučavam učenike sa smetnjama u razvoju, adekvatno sam obučen da prepoznam potrebe ovih učenika, verujem da je akademski napredak moguć kod ovih učenika...

Табела 1

Stavovi nastavnika prema inkluzivnim odeljenjima

\begin{tabular}{llllll}
\hline & Br. ispitanika & Prosečna vrednost & $\begin{array}{l}\text { Standardna } \\
\text { devijacija }\end{array}$ & Minimum & Maksimum \\
\hline Stavovi & 106 & 2,75 & 0,72 & 1,40 & 4,60 \\
\hline
\end{tabular}

Napomena:br-broj.

Iz tebele 1 možemo videti da je prosečan skor na ovoj skali iznosio 2,75 što nam ukazuje na to da nastavnici nisu u potpunosti sigurni kada je u pitanju njihovo slaganje sa svim tvrdnjama u okviru ovog upitnika, te da je njihov stav prema inkluzivnim odeljenjima samo blago pozitivan. 
Primenom skale koja se odnosi na emocionalne reakcije nastavnika prema deci sa smetnjama u razvoju - Emotional Reaction Scale ispitali smo emocionalne reakcije nastavnika prema deci sa različitim tipovima smetnji u razvoju. Izjave se odnose na to kako bi se nastavnici osećali kada bi u njihovo odeljenje došao učenik sa nekom od nabrojanih smetnji. Ispitanici su trebali da za svaku od ponuđenih izjava izraze svoje emocionalne reakcije na taj način što su zaokruživši broj od 1-7 izrazili svoje emocionalnu reakciju za svaku ponuđenu situaciju, pri čemu je 1 predstavlja manje pozitivne emocije -pesimistično, neugodno, negativno, u odnosu na 7 koja označava pozitivne emocije - pozitivno, ugodno, zainteresovano...

Ukupan prosečan skor na skali emocija iznosi je 4,49, što govori u prilog tome da su emocije nastavnika prema ovoj deci uglavnom pozitivne, ali ono što je potrebno naglasiti jeste to da se za svaku od ponuđenih situacija raspon odgovora kretao od 1 do 7, što nam ukazuje na to da su neki nastavnici imali potpuno negativne emocionalne reakcije za određenu situaciju dok su sa druge strane neki imali potpuno pozitivne emocionalne reakcije za istu tu situaciju.

Tabela 2

Emocionalne reakcije nastavnika

\begin{tabular}{lllll}
\hline Varijabla & $\begin{array}{l}\text { Prosečna } \\
\text { vrednost }\end{array}$ & $\begin{array}{l}\text { Standardna } \\
\text { devijacija }\end{array}$ & Minimum & Maksimum \\
\hline $\begin{array}{l}\text { 1.Ispodprosečno intelektualno } \\
\text { funkcionisanje }\end{array}$ & 4,50 & 1,43 & 1 & 7 \\
2.Oštećenje vida & 4,71 & 1,37 & 1 & 7 \\
3.Oštećenje sluha & 4,57 & 1,40 & 1 & 7 \\
4. Telesno oštećenje & 4,75 & 1,51 & 1 & 7 \\
5. Autizam & 3,87 & 1,58 & 1 & 7 \\
6. Daunov sindrom & 4,20 & 1,60 & 1 & 7 \\
7. Osnovna smetnja i smetnje u & 4,15 & 1,58 & 1 & 7 \\
ponašanju & & & & \\
8. Sa učenikom je i asistent & 4,40 & 1,57 & 1 & 7 \\
\hline Prosečan skor skale & 4,49 & 1,27 & 1 & 7
\end{tabular}

U tabeli 2 možemo da vidimo da su nastavnici najviše negativnih emocionalnih reakcije ispoljili prema deci sa autisitičnim spektrom poremećaja, dok su najpozitivnije emocionalne reakcije imali prema deci sa oštećenjem vida i prema deci sa telesnim oštećenjem. 
U okviru našeg istraživanja ispitali smo i to da li emocionalne reakcije nastavnika imaju pozitivan uticaj na njihove stavove, te smo koristeći Pirsonov koeficijent korelacije utvrdili da postoji statistički značajna korelacija srednjeg stepena između emocionalnih reakcija nastavnika i pozitivnih stavova prema procesu inkluzije (Tabela 3), odnosno utvrdili smo da će nastavnici koji ispoljavaju pozitivne emocionalne reakcije prema deci sa smetnjama u razvoju ispoljavati i pozitivnije stavove prema inkluziji u odnosu na nastavnike koji imaju manje pozitivne ili čak u potpunosti negativne emocionalne reakcije prema ovoj populaciji.

Табела 3

Povezanost emocionalnih reakcija nastavnika i pozitivnih stavova prema inklzuziji

\begin{tabular}{lll}
\hline & Emocionalne reakcije & $\mathrm{p}$ \\
\hline Stavovi & .58 & .001 \\
\hline
\end{tabular}

\section{Diskusija i zaključak}

Inkluzija podrazumeva integrisanje dece sa smetnjama u razvoju u redovne škole i uspostavljanje obrazovnog okvira koji će im najviše odgovarati (Radovanović, 2008). Pored prilagođavanja školskog okvira deci sa smetnjama u razvoju, neophodno je školske uslove prilagoditi i za drugu decu, odnosno „darovite učenike“ kako bi i oni mogli da razvijaju i unapređuju svoje sposobnosti i potencijale. Uloga nastavnika i učitelja u ovom procesu je od presudnog značaja, a emocije i stavovi koji preovladavaju kod najvećeg broja njih utiču na tok, ali i na konačan ishod samog procesa inkluzije, dakle, oni su ti koji sprovode inkluziju, te je upravo zbog toga potrebno posebnu pažnju posvetiti ispitivanju njihovih stavova (Rajović, Jovanović, 2010).

Rezultati našeg istraživanja ukazuju na blago pozitivne stavove nastavnika prema inkluziji $(2,75)$, što je veoma slično rezultatima koje su dobili Galović, D. Brojčin, B. Glumbić, N. (2014), koji su u okviru svog istraživanja obuhvatili 322 vaspitača i nastavnika osnovne i srednje škole, te rezultati koje su dobili u okviru istraživanja ukazuju na pozitivniju ali ipak dominantno neutralnu poziciju stavova nastavnika prema inkluziji (2.74) što se poklapa i sa našim rezultatima (Galović, D. Brojčin, B. Glumbić, N. 2014). Ono što je potrebno naglasiti je i to da mi u okviru našeg istraživanja vidimo blagi pomak u stavovima nastavnika prema inkluzivnom obrazovanju u pozitivnom smeru u odnosu na istraživanje: Inkluzivno obrazovanje: ideja i praksa (Jovanović-Popadić, 2016). Istraživanje je sprovedeno u Kruševcu na uzorku od 60 nastavnika (51 nastavnik iz redovnih osnovnih škola i 9 defektologa iz škole za decu sa smetnjama u razvoju). Rezultati ovog istraživanja ukazuju na to da su kod nastavnika dominantni negativni stavovi prema inkluziji, većina ovih nastavnika smatra da obrazovanje dece sa smetnjama u razvoju u specijalnim uslovima može da da bolje rezultate, pre svega zbog nedostatka sistemske podrške nastavnicima osnovnih škola u sprovođenju 
procesa inkluzije (Jovanović-Popadić, 2016). Sa ovim mišljenjem i mi možemo da se složimo jer je u okviru našeg uzorka od 106 nastavnika samo njih 25 prošlo neku adekvatnu vrstu obuke, samim tim i ne treba da nas čudi zašto iskustvo u radu sa ovom populacijom ne doprinosi pozitivnim stavovima nastavnika prema inkluziji, jer iskustvo u radu, bez adekvatne obuke ne može biti u potpunosti pozitivno.

U istraživanju „Procena stavova nastavnika prema inkluzivnom obrazovanju u urbanim školskim okruženjima u Irskoj“, autorka Ciara Mahony (2016) je koristila istu skalu za ispitivanje emocionalnih reakcija nastavnika prema deci sa smetnjama u razvoju koju smo i mi koristili u okviru našeg istraživanja. Autorka istraživanja je pretpostavila da će nastavnici imati znatno negativnije emocije prema deci sa smetnjama u ponašanju nego prema deci koja imaju neku smetnju u učenju, što je kasnije i potvrdila na osnovu rezultata koje je dobila (Mahony, 2016). U okviru našeg istraživanja nastavnici su najviše negativnih emocionalnih reakcija ispoljili prema učenicima sa autizmom, što se i uklapa u rezultate prethodno navedenog istraživanja jer su učenici sa autizmom, učenici koji najčešće ispoljavaju stereotipne i repetitivne obrasce ponašanja, ova ponašanja često remete druge učenike ali i sam rad nastavnika ili učitelja u toku časa, te je to često uzrok negativnih emocionalnih reakcija prema ovoj populaciji učenika. Osim toga u radu sa njima česte su i problemske situacije za čije rešavanje nastavnici sebe smatraju nedovoljno kompetentnima.

Najviše nastavnika koji su učestvovali u ovom istraživanju pozitivne emocije je pokazalo prema deci sa telesnim oštećenjem i prema deci sa oštećenjem vida, ovo možemo objasniti mišljenjem da je reč o deci koja su najčešće intelektualno očuvana i sa kojima naročito kada je reč o učenicima sa telesnim oštećenjem nisu potrebne posebne strategije podučavanja. Kada je reč o deci koja imaju oštećenje vida, nastavnici navode da ovi učenici ne ometaju druge vršnjake na času ali navode da su potrebna dodatna prilagođavanja za rad sa njima, ova prilagođavanja mogu da uključuju promenu mesta sedenja, korišćenje lupe, izrada teksta na papiru većeg formata i korišćenje većeg fonta slova, zatim i primena asistivne tehnologije i sredstava koja opet zavisi od resursa koje škola poseduje.

Ciara Mahony u prethodno navedenom istraživanju takođe navodi i to da se nastavnici i učitelji često osećaju nedovoljno spremno da zadovolje potrebe učenika sa smetnjama u razvoju, naročito ako je reč o učenicima koji imaju teži oblik invalidnosti. Težina ometenosti koju učenik ima značajno utiče na njihov stav prema procesu inkluzije. U svom istraživanju navodi i to da nastavnici najveću zabrinutost pokazuju prema obrazovanju učenika sa autističnim spektrom poremećaja, prema učenicima sa izazovnim ponašanjem i prema onim učenicima koji imaju umerene smetnje u učenju, što se poklapa i sa rezultatima našeg istražvanja jer su naši nastavnici najviše negativnih emocija pokazali upravo prema učenicima sa autizmom, za koje su i naveli da najviše ometaju druge učenike na času, a samim tim i njihov rad, a potom i prema učenicima koji pored osnovne smetnje pokazuju i neke smetnje u ponašanju (Mahony, 2016) 
Osnovno pravo svakog deteta bez obzira na sposobnosti, veštine i interesovanja koja poseduje je da se školuje u redovnoj školi zajedno sa svojim vršnjacima, odnosno da se školuje u inkluzivnom odeljenju, sredini koja će mu biti prilagođena i u okviru koje će sve njegove potrebe biti zadovoljene. Ključna ličnost u zadovoljenju ovih potreba je učitelj.

Upravo zbog važne uloge koju nastavnik ima u samom inkluzivnom procesu potrebno je ispitati njegove stavove i emocije koje su u osnovi stava, a zajedno u manjoj ili većoj meri motivišu ponašanje i aktivnosti nastavnika.

Na osnovu našeg rada možemo da zaključimo da nastavnici koji ispoljavaju pozitivne stavove prema inkluziji ispoljavaju i znatno pozitivnije emocionalne reakcije prema deci sa smetnjama u razvoju, upravo zbog toga postoji i veća mogućnost uspeha inkluzije u njihovoim odeljenjima nego u odeljenjima gde nastavnik ima manje pozitivne ili čak potpuno negativne emocije prema ovoj deci.

Još jedan zaključak koji možemo da iznesemo je i taj da je za uspeh inkluzije neophodno pripremiti nastavnike i učitelje za sam proces, pružiti im adekvatnu obuku i podršku, zatim obezbediti resurse i opremiti školu sredstvima i materijalima neophodnim za rad sa ovom decom. Na taj način će se olakšati rad nastavnika sa ovom populacijom i obezbediti pozitivno iskustvo u interakciji sa njima koje će kasnije pozitivno uticati na stavove nastavnika i učitelja i obezbediti kvalitetno obrazovanje svakom detetu.

\title{
Anđa Zobenica, Ksenija Kolunndžija
}

\section{DO TEACHERS' ATTITUDES TOWARDS INCLUSION CHANGE?}

\begin{abstract}
Inclusive education represents a major change in the educational process. For the success of this process, all actors involved in it are crucial. For this reason, the aim of this research was to determine the attitudes and emotional reactions of teachers towards inclusion process. Three questionnaires were used in the research: Questionnaire of general demographic data, Scale of Teacher's Attitudes Toward Inclusive Classrooms and Emotional Reaction Scale. The research involved 106 teachers from eight elementary schools on the territory of Vojvodina. The results of the research indicate that teachers' attitudes towards inclusion are only slightly positive (2.75), emotional responses towards children with disabilities are positive (4.49), and the teachers who exhibit positive emotional responses towards children with developmental disabilities will also exhibit more positive attitudes towards inclusion than teachers with less
\end{abstract}


positive or even negative emotional reactions $(\mathrm{r}=.58, \mathrm{p}<.01)$. The success of inclusion is considerably higher in the classrooms where teachers' emotional reactions and their attitudes are positive in comparison with the classrooms where they are negative.

Key words: Inclusion, Special educational needs, Attitudes.

\section{Literatura}

Borić, S.,\& Tomić, R. (2012). Stavovi nastavnika osnovnih škola o inkluziji. A. Rotar, M. Ružić Baf, \&M. Radetić-Paić (Ur.), Metodički obzori (pp.75-85). Pula, Alfio Barbieri, PhD.

Brojčin, B. (2013). Inkluzivna edukacija. Beograd: Univerzitet u Beogradu-Fakultet za specijalnu edukaciju i rehabilitaciju.

Đorđević, S. Đorđević L. (2014). Teorija i praksa inkluzivnog obrazovanja. S. Denić (Ur.), Godišnjak učiteljskog fakulteta u Vranju (pp.115-127). Vranje,Učiteljski fakultet.

Galović, D., Brojčin, B.,\&Glumbić, N. (2014). The attitudes of teachers towards inclusive education in Vojvodina. International Journal of Inclusive Education, 12, 1262-1282.

Giaccchi, D. (2003). Teachers attitudes towards inclusion (dissertation). New Jersey: Rowan University.

Hargreaves, A. (2004). Inclusive and exclusive educational change: emotional responses of teachers and implications for leadership. School Leadership \& Management, 2, 288-307.

Jovanović-Popadić, A. (2016). Inkluzivno obrazovanje: Ideja i praksa. Sinteze, 10, 3546.

Mahony, C. (2016). Assessing Teachers Attitudes toward Inclusive Education Within an Urban School District in Ireland. Retrieved March 2018 from https://esource.dbs.ie/bitstream/handle/10788/3155/hdip_mahony_c_2016.pdf?sequence $=1 \&$ isAllowed $=y$

Radovanović, D. (2008). Ususret inkluziji - dileme u teoriji i praksi. Beograd: Univerzitet u Beogradu-Fakultet za specijalnu edukaciju i rehabilitaciju.

Rajović, V., \& Jovanović, O. (2010). Profesionalno i privatno iskustvo sa osobama sa posebnim potrebama i stavovi nastavnika redovnih škola prema inkluziji. Psihološka istraživanja, 1, 91-106.

Walker, J.T. (2017). Attitudes and Inclusion: An Examination of Teachers Attitudes Toward Including Studentas with a Disabilities (dissertation). Chicago: Loyola University Chichago. 